\title{
First report of tomato brown rugose fruit virus infecting bell pepper in Iran
}

\author{
Fereshteh Esmaeilzadeh ${ }^{1} \cdot$ Davoud Koolivand ${ }^{1}$ (])
}

Received: 28 January 2022 / Accepted: 26 February 2022 / Published online: 3 March 2022

(c) The Author(s) under exclusive licence to Società Italiana di Patologia Vegetale (S.I.Pa.V.) 2022

Keywords Iran · Pepper $\cdot$ Phylogentic analyis · Tomato brown rugose fruit virus

In 2021, a new disease caused by tomato brown rugose fruit virus has emerged in greenhouse-grown tomato plants in Iran (Esmaeilzadeh and Koolivand 2021; Ghorbani et al. 2021). In late December of 2021, greenhouse-grown pepper plants showed brown-colored spots and deformed fruits. Most symptomatic plants were bell peppers cultivated on approximately 3 hectares. Based on the symptomatology, the presence of TBRFV was suspected in diseased bell peppers. To test for TBRFV in bell pepper plants, total RNA was extracted from symptomatic leaves and fruits of 12 plants by the CTAB method (Gambino et al. 2008) and used in RT-PCR with primers ToBRFV-F-5722 (5'-CACAATCGC AACTCCATCGC-3') and ToBRFV-R-6344 (5'-GTGCCT ACGGATGTGTATGA-3 to amplify a 623-bp fragment corresponding to the coat protein gene. The expected fragments were amplified in five suspected samples that was around $41.7 \%$ of plants symptomatic, and one isolate was sequenced as representative of the monitored greenhouse. Sequence analyses showed that the Iranian TBRFV isolate from bell pepper had high nucleotide identity with TBRFV isolates from tomato in Iran (99\%), the USA, the Netherland, and Turkey. Phylogenetic analyses of the complete CP gene sequence by the neighbor joining method in MEGAX confirmed the relationship of the Iranian TBRFV isolate from bell pepper and other isolates. The sequence of the Iranian TBRFV isolate from bell pepper was deposited in GenBank as accession number OM386673. For biological assays, tobacco plants (Nicotiana rustica) were mechanically inoculated with sap from TBRFV-infected leaves and resulted in the development of necrotic local ring on leaves at 3 days post-inoculation. TBRFV causes economic losses in tomato and pepper as infected fruits cannot be exported to other countries. Therefore, effective management practices should be put in place to prevent the spread of TBRFV in virus-free locations in the country. To the best of our knowledge, this is the first report of TBRFV in pepper in Iran.

\section{Declarations}

Conflict of interest The authors declares that there are no conflict of interest.

\section{References}

Esmaeilzadeh F, Koolivand D (2021) Occurrence of tomato brown rugose fruit virus in tomato in Iran. J Plant Pathol. https://doi.org/ 10.1007/s42161-021-01009-7

Gambino G, Perrone I, Gribaudo I (2008) A Rapid and Effective Method for RNA Extraction from Different Tissues of Grapevine and Other Woody Plants. Phytochem Anal 19:520-525

Ghorbani A, Rostami M, Seifi S, Izadpanah K (2021) First report of Tomato brown rugose fruit virus in greenhouse tomato in Iran. New Dis Rep. https://doi.org/10.1002/ndr2.12040

Publisher's Note Springer Nature remains neutral with regard to jurisdictional claims in published maps and institutional affiliations.

Davoud Koolivand

Koolivand@znu.ac.ir

1 Department of Plant Protection, Faculty of Agriculture,

University of Zanjan, Zanjan, Iran 